\title{
Evaluation of the health attention to pregnant women with HIV: comparison between primary and specialized service ${ }^{a}$
}

Avaliação da atenção à saúde de gestantes com HIV: comparação entre serviço primário e especializado

Evaluación de la atención de salud a mujeres embarazadas con VIH: comparación entre servicio primario y especializado

Raquel Einloft Kleinubing ${ }^{1}$

Daniel Gonzalo Eslava² ${ }^{2}$

Stela Maris de Mello Padoin ${ }^{1}$ (1)

Cristiane Cardoso de Paula ${ }^{1}$ (C)

1. Universidade Federal de Santa Maria. Santa Maria, RS, Brasil.

2. Fundación Universitaria del Área Andina. Bogotá, Colombia.
Corresponding author:

Cristiane Cardoso de Paula.

E-mail: cristiane.paula@ufsm.br.

Submitted on $08 / 25 / 2018$

Accepted on 01/04/2019.

DOI: 10.1590/2177-9465-EAN-2018-0258

\begin{abstract}
The public network for health care of pregnant women with HIV, in Santa Maria, Rio Grande do Sul/Brazil, includes primary and specialized care services. Objective: Evaluating whether the type of service interferes in the quality score of the health care in the experience of the pregnant women with HIV. Methods: Cross-sectional study, with data collection from April-November/2014 with 78 participants. The Primary Care Assessment Tool-Brazil instrument was applied and the Pearson's Chi-square test and Fisher's exact test were used. Results: The quality of care received was evaluated as unsatisfactory both in primary care (6.50) and in specialized care (6.35). Conclusion: The type of service interferes with the quality of care, which can affect women's choice of service. It is necessary to improve the quality of both types of services and to search for the management of shared care to attend both the usual pregnancy care and the specificity of infection.
\end{abstract}

Keywords: Health Care; Health Services Research; Women's Health; Pregnant Women; HIV.

\section{Resumo}

A rede pública para atenção à saúde de gestantes com HIV, no município de Santa Maria, Rio Grande do Sul/Brasil, inclui os serviços de atenção primária e especializada. Objetivo: Avaliar se o tipo de serviço interfere no escore de qualidade da atenção à saúde na experiência das gestantes com HIV. Métodos: Estudo transversal, com coleta de dados de abril-novembro/2014 com 78 participantes. Foi aplicado o instrumento Primary Care Assessment Tool-Brasil e utilizados os testes Qui-quadrado de Pearson e Exato de Fisher. Resultados: A qualidade da atenção recebida foi avaliada como insatisfatória tanto na atenção primária $(6,50)$ quanto na especializada $(6,35)$. Conclusão: $O$ tipo de serviço interfere na qualidade da atenção, o que pode repercutir na escolha do serviço pelas mulheres. Há necessidade de melhoria da qualidade de ambos os serviços e de busca pelo cuidado compartilhado para atender tanto cuidados habituais da gestação quanto especificidade da infecção.

Palavras-chave: Atenção à Saúde; Avaliação de serviços de saúde; Saúde da Mulher; Gestantes; HIV.

\section{Resumen}

La red pública de atención de salud de mujeres embarazadas con VIH, en Santa María, Rio Grande do Sul/Brasil, incluye servicios de atención primaria y especializada. Objetivo: Evaluar si el tipo de servicio interfiere en el puntaje de calidad de la atención de salud en la experiencia de las mujeres embarazadas con VIH. Métodos: estudio transversal, con la recolección de datos de abril-noviembre/2014, con 78 participantes. Se aplicó el instrumento Primary Care Assessment Tool-Brasil y se utilizaron la prueba de Chi-cuadrado de Pearson y exacta de Fisher. Resultados: La calidad de la atención recibida fue evaluada insatisfactoria tanto en la atención primaria $(6,50)$ como en la especializada $(6,35)$. Conclusión: El tipo de servicio interfiere en la calidad de la atención, lo que puede repercutir en la elección del servicio por las mujeres. Hay necesidad de mejorar la calidad de ambos servicios y buscar el cuidado compartido para atender tanto cuidados habituales de la gestación como especificidad de la infección.

Palabras clave: Atención a la Salud; Investigación en Servicios de Salud; Salud de la Mujer; Mujeres Embarazadas; VIH. 


\section{INTRODUCTION}

The quality of attention for the health of pregnant women living with the Human Immunodeficiency Virus (HIV) has repercussions both in maternal and neonatal health, especially regarding to the success of the vertical transmission (VT) prophylaxis. The prophylaxis actions and maternal and child chronic condition management were listed as one of the priorities for the Single Health System (SUS) in Brazil, faced with the fact that the goal of eradicating the VT had not been complied with. Therefore, the performance of HIV diagnosis tests in the pre-natal follow-up should be available, and the provision of the anti-retroviral therapy for women and children exposed to the infection and the maintainance of the clinical follow-up during pregnancy should be implemented. ${ }^{1}$

In face of the double vulnerability marked by the gestational period and by the serological condition, it is necessary that the services of different technological densities which compose the Health Care Network $(\mathrm{HCN})$ remain integrated to meet these pregnant women's specific demands ${ }^{2}$. These services vary from less technological level (PHC), intermediate density (secondary attention), to greater technological density (tertiary attention to health). ${ }^{3}$ The $\mathrm{PHC}$, with strategic character in the structuring of interventions, should promote the contact with individuals, family and community and coordinate the transfer flows among the points of the HCN. The specialized services consist of secondary and tertiary points of attention. ${ }^{4}$

This integration indicates the shared management of care for people living with the HIV, in order to strengthen the access to the diagnosis, to start treatment at the appropriate time and to keep the follow-up. ${ }^{5}$ This points out the need for the specialized services' professionals to share the clinical management knowledge with $\mathrm{PHC}$ network professionals. Also, professionals who work in the PHC need to inform the professionals from the specialized service about the prevention and promotion actions developed in this forum, so it can strengthen the care and give continuity to the creation and execution of protocols and health public policies.

However, predominantly, the actions of attention to the pregnant women with this condition are maintained by the specialized services and seem to address their needs, independent of the complexity of the health condition. This fact meets the proposal to establish a $\mathrm{HCN} .^{6}$ The implication is that the identification of the health service which pregnant women living with HIV use as reference for continuity of care is achieved by means of an affiliation to a specialized service. And, when the services offer a curative assistance, instead of a preventive and of health promotion one, they compromise, thos, the quality of the assistance provided, in addition to the affiliation, the link, the integration of the care and the longitudinality. ${ }^{7}$

Therefore, the quality of the attention to health during the gestational period can be evaluated in the services in order to identify how much the users' needs are being met. ${ }^{8,9}$ Moreover, it is safeguarded to understand that the evaluation constitutes one of the mechanisms indicated to address the needs of planning and decision-making in the health field.

In the face of this proposal, from the emphasis on the $\mathrm{PHC}$ and the reality of the attention to these pregnant women (centralized in the specialized service), validated instruments are needed to assess the performance of services in different levels of attention, aiming at qualifying them. What indicated the purpose of this study: to evaluate if the type of service interferes in the health attention quality score, according to the PCATool-Brazil, in the experience of the pregnant women living with HIV.

\section{METHOD}

Cross-sectional study developed in the public health network for attention to pregnant women living with HIV, in Santa Maria, central region of the State of Rio Grande do Sul, Brazil. City with approximately 300,000 inhabitants, $31 \mathrm{PHC}$ services, of which 18 are traditional Basic Health Units (BHU) with population coverage of $21 \%, 13$ are Family Health Strategy (FHS) with coverage of $19 \%$. According to national data on the epidemic, Santa Maria occupied, in 2014, year of this research's data collection, the $10^{\text {th }}$ position in the national ranking of 100 cities with more than 100 , 000 inhabitants, according to composite index. At present, Santa Maria occupies the $94^{\text {th }}$ position. Among the first 20 ranked, ten belong to the South region, six of which in Rio Grande do Sul (RS), which reaffirms the need for assessment of the quality of the services that assist this population. Santa Maria counts on two HIV specialized services, one municipal and other the latter being a teaching hospital, and a reference for 32 cities of the state, members of the $4^{\text {th }}$ Healthcare Regional Coordinator.

The study's population consisted of women living with HIV $(n=109)$. The inclusion criteria were: those who used the PHC public services during the gestational period (2012 to 2014). Abortions and stillbirths were excluded. The access to the woman occurred in the PHC services and in the specialized services. It is emphasized that in the federal service the search occurred in the sectors: adult and pediatric outpatients for infectious diseases, maternity and high risk prenatal outpatient. The choice of these services is justified by the organization of the same, which regular agenda of attendance provided access to the study population. The total population was 78 participants. There were two refusals and 29 losses, due to absenteeism in the consultations.

This number of participants is justified considering the fact that it is a vulnerable population either by the HIV infection, or the gestational period. Stigmatized, the women living with HIV are reluctant to participate in the researches, also for protection of the diagnosis secrecy, shared in a restrict support network. The telephone contact information in the notification forms and/ or medical records do not keep up to date. The women change $\mathrm{PHC}$ services and access the specialized services outside the city of residence, sometimes, for the birth also. Either in the geographical sense, or in the psychosocial sense, it is confirmed as a population of difficult access, which reiterates the relevance of researches with women living with HIV, more specifically regarding the gestational period.

The data collection occurred during the period from April to 
November 2014. A research instrument composed of the characterization of the socio-demographic and clinical profile was used; as well as the Primary Care Assessment Tool-Brazil (PCATool) reduced Adult version, which was applied in a presence way and the access to women was through the health service.

The PCATool aims to assess how much the health services are oriented to the defining attributes of the PHC: access, coordination, integrality and longitudinality. An instrument developed by Barbara Starfield and applied in a national and international way. ${ }^{10,11}$ During the two decades after its creation in the United States of America (USA), this instrument was adapted for the health systems in Spain ${ }^{12}$, South Korea ${ }^{13} \mathrm{China}^{14}$, New Zealand ${ }^{15}$, Brazil $^{8}$, Argentina ${ }^{16}$ and Uruguay ${ }^{17}$. The interest in Latin America led to the creation of the (IA-PCAT) Ibero-American Cooperation, composed of researchers of Equator, Colombia, Mexico and Bolivia, which started the transcultural adaptation process, for health systems and services evaluation with the possibility of comparisons. ${ }^{8,12-17}$

The PCATool reduced Adult version is composed of a Likert type scale and the possible answers for each item of the instrument are: "yes, certainly" (value = four), "probably yes" (value $=$ three), "probably not" (value $=$ two), "certainly not" (value $=$ one) and "I don't know/I don't remember" (value = nine). ${ }^{9}$

The preferred type of service for the attention to the pregnant women's health was defined from three initial questions of the PCATool that establish the Degree of Affiliation regarding the service or professional that looks for, faced with a need, the one who knows well enough the pregnant woman and who is more responsible (involved) for her care. ${ }^{9}$ The other items were answered considering this affiliation. For analysis of the data, the answers were dichotomized as: PHC service and specialized service.

The socio-demographic variables were composed of: age, skin color (self-reported), housing city, marital status, instruction, occupation and clinical variables of the pregnancy: year of notification of the pregnancy in the Information of Diseases Notification System (SINAN), use of antiretroviral before and after pregnancy, route of infection, time of diagnosis and the carrying out of prenatal care.

For the quantitative variables (age and instruction), the median was employed as cutoff point due to the asymmetrical distribution of the data. The data were typed in the Epi Info version 7.0, using independent double entry, with check for errors and inconsistences, in order to guarantee accuracy of data.

The analysis of data was realized in the Predictive Analytics Software (PASW) version 18.0 for Windows. The internal consistency of the components of the PCATool was evaluated by means of the Cronbach's Alpha $(a=0.893)$. The attributes were analyzed by means of the calculation of the overall score ${ }^{9}$, since the reduced version does not allow the assessment per attribute. The scores' values were transformed into a continuous scale ranging from zero to 10 , in which the score $\geq 6.6$ was considered satisfactory. This value equates, in a scale ranging from one to four, to the score three ("probably yes") that corresponds to the adequate extension of the attribute. ${ }^{9}$
The Pearson Chi-square test or the Fisher's exact test were employed both for the analysis of association of variables to the service that regularly assisted the pregnant women (socio-demographic and clinical of the pregnancy), and to analyze the proportions and to identify which of these variables could be associated to the quality of attention of the service referred to as regular source of attention to health. For this purpose, it was dichotomized, regarding the score attributed, in high or satisfactory $(\geq 6.6)$ and low $(<6.6)$ score. The significance level assumed in the tests was $5 \%$.

The ethical aspects contained in the Resolution CNS 466/12 were met. The Informed Consent Form (ICF) and the Confidentiality Term were offered. This research was approved by the Research Ethics Committee of the Federal University of Santa Maria, under protocol 773.483 .

\section{RESULTS}

Among total participants $(n=78)$, the majority $(74.4 \%)$ referred to the PHC services as the regular source of attention to health during the gestational period for the occurrence of health problems or in the search for the professionals' orientations. The PHC was indicated as the service that best knew them (58.9\%) and as the service with greater responsibility for their health during pregnancy (39.7\%). These questions defined the degree of affiliation to the $\mathrm{PHC}$ service.

Among the socio-demographic variables, the housing city $(p=0.035)$ was significantly associated with the affiliation of the user to the PHC for attention to pregnancy, in HBU or FHS. Among the clinical variables, the use of antiretroviral before the pregnancy $(p=0.038)$ was significant to the user's affiliation to the specialized service; and use of antiretroviral during pregnancy $(p=0.031)$ was significant both for affiliation to the PHC and for specialized (Table 1).

The participants considered the quality of the attention received low, even next to a satisfactory score $(\geq 6.6)$, both in the primary attention (6.50) and in the specialized (6.35). (Table 2).

The analysis of association between the characteristics (sociodemographic and clinical) and the best assessment of the attention (high overall score) and lowest assessment of the attention (low overall score), was conducted in accordance with the type of service, established by the degree of affiliation (Table 3 ).

By evaluating the population characteristics associated with the PHC overall score, it did not show a significant difference that would be associated with low/high score, indicating that the population characteristics may not have interfered in the evaluation of the attention of both services.

\section{DISCUSSION}

The PHC services, as regular source of attention to health during the gestational period, prevailed among the evaluation in the participants' experience. The regular source recommends the users' affiliation for a service or professional and reinforces the importance of its role in receiving, advising the women in the 
infection management, monitoring in the pregnancy and puerperal cycle, mainly, with regard to social and family cohabitation, healthcare routine and, even, reproductive planning.

Similar result was found in studies conducted on the remaining communities of Brazilian Quilombos, in which the $\mathrm{PHC}$ was referred to maternal and child healthcare as entrance door for the most of users. The results indicated the reasons for affiliation to the service, the proximity of housing and the quality of attention, in spite of the difficulty of access to the services . ${ }^{11}$ Being the PHC the regular source of attention, it is necessary to minimize the barriers of the care's first contact and continuity..$^{18}$ In this way, the coordination of health attention to people living with HIV, under the incentive of the current national policy of the PHC, signals the care's decentralization process, historically constructed in the specialized services for the access, in the services of $\mathrm{FHS}$ and $\mathrm{HBU}$, to the consultations, vaccination and medicines or preservatives withdrawal, as well as gynecological and clinical follow-up. ${ }^{5}$

The analysis of the socio-demographic characteristics of the pregnant women living with HIV indicated that the housing city was significantly associated with the user's affiliation to the PHC. One may infer that using the PHC as regular source of attention can be related to the HBU and FHS localization. The affiliation to the $\mathrm{PHC}$ comes from actions such as the respect for people, confidentiality and the communication with the professionals, which tends to facilitate the access and the link both with the service and with the health team's professionals. ${ }^{19}$ This demonstrates that the Brazilian public sector has been investing in the PHC through better indicators of attention coverage during the gestational period, including in the solicitation of anti-HIV testing. ${ }^{20}$

The clinical characteristics show that most pregnant women who used antiretroviral previously to pregnancy indicated the specialized service as affiliation. In the users' experience, the positive evaluation of these services is related to the confidence, knowledge and commitment of the professionals, as well as agility for problem resolution. ${ }^{21}$ In the evaluation of the services, it can be pointed out the importance of the permanent investment in actions of promotion and monitoring of the treatment, that offer support to meet the needs of each and everyone. ${ }^{22}$

The multidisciplinary, integral and multidimensional approach that involves the treatment ${ }^{23}$ reinforces the need for decentralization of the attention to people living with HIV. This movement from a model centralized in the specialized service to a matrix model has favorable factors such as the perspective

Table 1. Características sociodemográficas e clínicas de gestante vivendo com HIV, segundo o tipo de serviço como fonte regular da atenção. Santa Maria, 2014. ( $N=78)$

\begin{tabular}{|c|c|c|c|c|c|}
\hline & & & $\mathrm{PHC}(\mathrm{N}=58)$ & $\begin{array}{c}\text { Specialized Service } \\
(\mathrm{N}=20)\end{array}$ & \\
\hline Characteristics & Variables & Categories & N (\%) & N (\%) & $P$ \\
\hline \multirow{20}{*}{ Socio-demographic } & \multirow{4}{*}{ Age } & & & & $0.071^{*}$ \\
\hline & & Up to 20 years & $8(10.26)$ & $0(0.00)$ & \\
\hline & & 21 to 30 years & 27 (34.62) & $7(8.97)$ & \\
\hline & & $>30$ years & 23 (29.49) & $13(16.67)$ & \\
\hline & \multirow{3}{*}{ Housing city } & & & & $0.035^{*}$ \\
\hline & & Santa Maria & $38(48.72)$ & $18(23.08)$ & \\
\hline & & Other & $20(25.64)$ & $2(2.56)$ & \\
\hline & \multirow{3}{*}{ Marital status } & & & & $0.359 *$ \\
\hline & & Married & $37(47.44)$ & 15 (19.23) & \\
\hline & & Single & $21(26.92)$ & $5(6.41)$ & \\
\hline & \multirow{3}{*}{ Schooling ( $N=77$ ) } & & & & $0.563^{* *}$ \\
\hline & & Yes & $54(70.13)$ & $20(25.97)$ & \\
\hline & & No & $3(3.90)$ & $0(0.00)$ & \\
\hline & \multirow{3}{*}{ Monthly income } & & & & $0.077^{*}$ \\
\hline & & Up to $R \$ 1000$ & $39(50.00)$ & $9(11.54)$ & \\
\hline & & $>\mathrm{R} \$ 1000$ & $19(24.36)$ & $11(14.10)$ & \\
\hline & \multirow{4}{*}{ Occupation } & & & & $0.982 *$ \\
\hline & & None & $6(7.69)$ & $2(2.56)$ & \\
\hline & & Irregular employment & $47(60.26)$ & $16(20.51)$ & \\
\hline & & Regular employment & $5(6.41)$ & $2(2.56)$ & \\
\hline
\end{tabular}




\begin{tabular}{|c|c|c|c|c|c|}
\hline & & & $\mathrm{PHC}(\mathrm{N}=58)$ & $\begin{array}{c}\text { Specialized Service } \\
(\mathrm{N}=20)\end{array}$ & \\
\hline Characteristics & Variables & Categories & $\mathrm{N}(\%)$ & N (\%) & $P$ \\
\hline \multirow{25}{*}{ Clinics } & \multirow{5}{*}{$\begin{array}{l}\text { Year of notification } \\
\text { SINAN\#- pregnancy } \\
\qquad(N=76)\end{array}$} & & & & $0.653^{*}$ \\
\hline & & Year 2012 & $10(13.16)$ & $3(3.95)$ & \\
\hline & & Year 2013 & $17(22.37)$ & $7(9.21)$ & \\
\hline & & Year 2014 & $18(23.68)$ & $4(5.26)$ & \\
\hline & & Notification not found & $11(14.47)$ & $6(7.89)$ & \\
\hline & \multirow{3}{*}{$\begin{array}{l}\text { Use of antirretro- } \\
\text { viral before preg- } \\
\text { nancy }\end{array}$} & & & & $0.038 *$ \\
\hline & & Yes & $17(21.79)$ & $11(14.10)$ & \\
\hline & & No & $41(52.56)$ & $9(11.54)$ & \\
\hline & \multirow{3}{*}{$\begin{array}{l}\text { Use of antiretroviral } \\
\text { during pregnancy }\end{array}$} & & & & $0.031 * *$ \\
\hline & & Yes & $41(52.56)$ & $19(24.36)$ & \\
\hline & & No & 17 (21.79) & $1(1.28)$ & \\
\hline & \multirow{3}{*}{$\begin{array}{l}\text { Route of HIV infec- } \\
\text { tion }\end{array}$} & & & & $0.294 *$ \\
\hline & & Sexual & $36(46.15)$ & 15 (19.23) & \\
\hline & & Unknown & $22(28.21)$ & $5(6.41)$ & \\
\hline & \multirow{5}{*}{$\begin{array}{l}\text { Moment of the } \\
\text { diagnosis of the } \\
\text { infection of HIV }\end{array}$} & & & & $0.261^{*}$ \\
\hline & & Before pregnancy & $33(42.31)$ & $16(20.51)$ & \\
\hline & & During pregnancy & $20(25.64)$ & $4(5.13)$ & \\
\hline & & During birth & $4(5.13)$ & $0(0.00)$ & \\
\hline & & After birth & $1(1.28)$ & $0(0.00)$ & \\
\hline & \multirow{3}{*}{$\begin{array}{l}\text { Attending prenatal } \\
\text { care }\end{array}$} & & & & $1.000 * *$ \\
\hline & & Yes & 56 (71.79) & 19 (24.36) & \\
\hline & & No & $2(2.56)$ & $1(1.28)$ & \\
\hline & \multirow{3}{*}{$\begin{array}{l}\text { Number of prenatal } \\
\text { consultations }(\mathrm{N}= \\
74)\end{array}$} & & & & $1.000 * *$ \\
\hline & & $\begin{array}{l}\text { Up to } 14 \text { consulta- } \\
\text { tions }\end{array}$ & $51(68.92)$ & $18(24.32)$ & \\
\hline & & $\begin{array}{l}\text { Above } 14 \text { consulta- } \\
\text { tions }\end{array}$ & $4(5.41)$ & $1(1.35)$ & \\
\hline
\end{tabular}

Table 2. Comparison among the means of overall score among the types of services referred to as regular source of attention. Santa Maria, 2014. ( $\mathrm{N}=78)$

\begin{tabular}{lcccccc}
\hline $\begin{array}{l}\text { Overall score for } \\
\text { service }\end{array}$ & Mean & $\begin{array}{l}\text { Standard } \\
\text { Deviation }\end{array}$ & Median & Minimum & Maximum & $\mathrm{p}^{* *}$ \\
\hline PHC $(\mathrm{N}=58)^{+}$ & 6.50 & 2.27 & 7.36 & 1.58 & 9.57 & 0.698 \\
Specialized*(N=18) & 6.35 & 1.50 & 6.07 & 3.92 & 9.41 & \\
† Asymmetrical distribution & & & & & & \\
* Normal distribution & & & & & & \\
** Mann-Whitney Test & & & & & &
\end{tabular}


of work in the PHC, according to the SUS principles and of the family health, training and matrix support. However, there are challenges such as incomplete teams, professionals' turnover, work overload, counselling and communication of the diagnosis. ${ }^{24}$ In addition, there is lack of communication among the points that compose the $\mathrm{HCN}$, which can entail negatively the continuity of the attention. ${ }^{6}$

It was also identified that most participants, regardless of the service used as regular source of attention, used antiretroviral drugs during pregnancy. Which may indicate that, independent of the previous use of antiretroviral drugs, during this period, the women living with HIV adhere to vertical transmission prophylaxis in the service of affiliation.

Regarding the evaluation of the quality in the experience of the pregnant women living with HIV, both services presented unsatisfactory general values, being the $\mathrm{PHC}$ closer to the value

Table 3. Sociodemographic and clinical characteristics of pregnant women living with the HIV with the high /low score, regarding the type of service referred to as regular source of attention. Santa Maria, 2014. (N=78)

\begin{tabular}{|c|c|c|c|c|c|c|c|c|}
\hline & & & PHC Ser & ce $(N=56)$ & & Specialized & ervice $(N=1 \varepsilon$ & \\
\hline & Variables & Categories & $\begin{array}{c}\text { High } \\
\text { score } \\
(\geq 6.6) \\
\end{array}$ & $\begin{array}{c}\text { Low } \\
\text { score } \\
(\geq 6.6) \\
\end{array}$ & $\mathrm{p}$ & $\begin{array}{l}\text { High } \\
\text { score } \\
(\geq 6.6) \\
\end{array}$ & $\begin{array}{c}\text { Low score } \\
(\geq 6.6)\end{array}$ & $\mathrm{P}$ \\
\hline & & & $\mathrm{N}(\%)$ & $\mathrm{N}(\%)$ & & $\mathrm{N}(\%)$ & $\mathrm{N}(\%)$ & \\
\hline \multirow{20}{*}{$\begin{array}{l}\text { Sociodemogra- } \\
\text { phic characte- } \\
\text { ristics }\end{array}$} & \multirow{7}{*}{$\begin{array}{l}\text { Skin color (self- } \\
\text {-reported) }\end{array}$} & & & & $0.903 *$ & & & $0.354 *$ \\
\hline & & Up to 20 years & $5(8.62)$ & $3(5.17)$ & & $-(-)$ & $-(-)$ & \\
\hline & & 21 to 30 years & $\begin{array}{c}15 \\
(25.86)\end{array}$ & $\begin{array}{c}12 \\
(20.69)\end{array}$ & & $1(5.00)$ & $6(30.00)$ & \\
\hline & & $>30$ years & $\begin{array}{c}14 \\
(24.14)\end{array}$ & $9(15.52)$ & & $5(25.00)$ & $8(40.00)$ & \\
\hline & & & & & $0.176^{*}$ & & & $0,612^{* *}$ \\
\hline & & White & $\begin{array}{c}11 \\
(18.97)\end{array}$ & $\begin{array}{c}12 \\
(20.69)\end{array}$ & & $5(25.00)$ & $9(45.00)$ & . \\
\hline & & Not white & $\begin{array}{c}23 \\
(39.66)\end{array}$ & $\begin{array}{c}12 \\
(20.69)\end{array}$ & & $1(5.00)$ & $5(25.00)$ & \\
\hline & \multirow{4}{*}{ Housing City } & & & & $0,877^{*}$ & & & $0,078^{* *}$ \\
\hline & & Santa Maria & $\begin{array}{c}22 \\
(37.93)\end{array}$ & $\begin{array}{c}16 \\
(27.59)\end{array}$ & & $4(20.00)$ & $14(70.00)$ & \\
\hline & & Other & $\begin{array}{c}12 \\
(20.69)\end{array}$ & $8(13.79)$ & & $2(10.00)$ & $0(0.00)$ & \\
\hline & & & & & $0.348 *$ & & & $1.000 * *$ \\
\hline & \multirow{2}{*}{ Marital Status } & Married & $\begin{array}{c}20 \\
(34.48)\end{array}$ & $\begin{array}{c}17 \\
(29.31)\end{array}$ & & $5(25.00)$ & $10(50.00)$ & \\
\hline & & Single & $\begin{array}{c}14 \\
(24.14)\end{array}$ & 7 (12.07) & & $1(5.00)$ & $4(20.00)$ & \\
\hline & \multirow{4}{*}{$\begin{array}{l}\text { Instruction } \\
(\mathrm{N}=77)\end{array}$} & & & & $0,069 * *$ & & & - \\
\hline & & Yes & $\begin{array}{c}33 \\
(57.89)\end{array}$ & $\begin{array}{c}21 \\
(36.84)\end{array}$ & & $6(30.00)$ & $14(70.00)$ & \\
\hline & & No & $0(0.00)$ & $3(5.26)$ & & $-(-)$ & $-(-)$ & \\
\hline & & & & & $0,902 *$ & & & $0.342 *$ \\
\hline & \multirow{3}{*}{ Occupation } & None & $3(5.17)$ & 3 (5.17) & & $0(0.00)$ & $2(10.00)$ & \\
\hline & & $\begin{array}{l}\text { Irregular em- } \\
\text { ployment }\end{array}$ & $\begin{array}{c}28 \\
(48.28)\end{array}$ & $\begin{array}{c}19 \\
(32.76)\end{array}$ & & $6(30.00)$ & $10(50.00)$ & \\
\hline & & $\begin{array}{l}\text { Regular employ- } \\
\text { ment }\end{array}$ & $3(5.17)$ & $2(3.45)$ & & $0(0.00)$ & $2(10.00)$ & \\
\hline
\end{tabular}




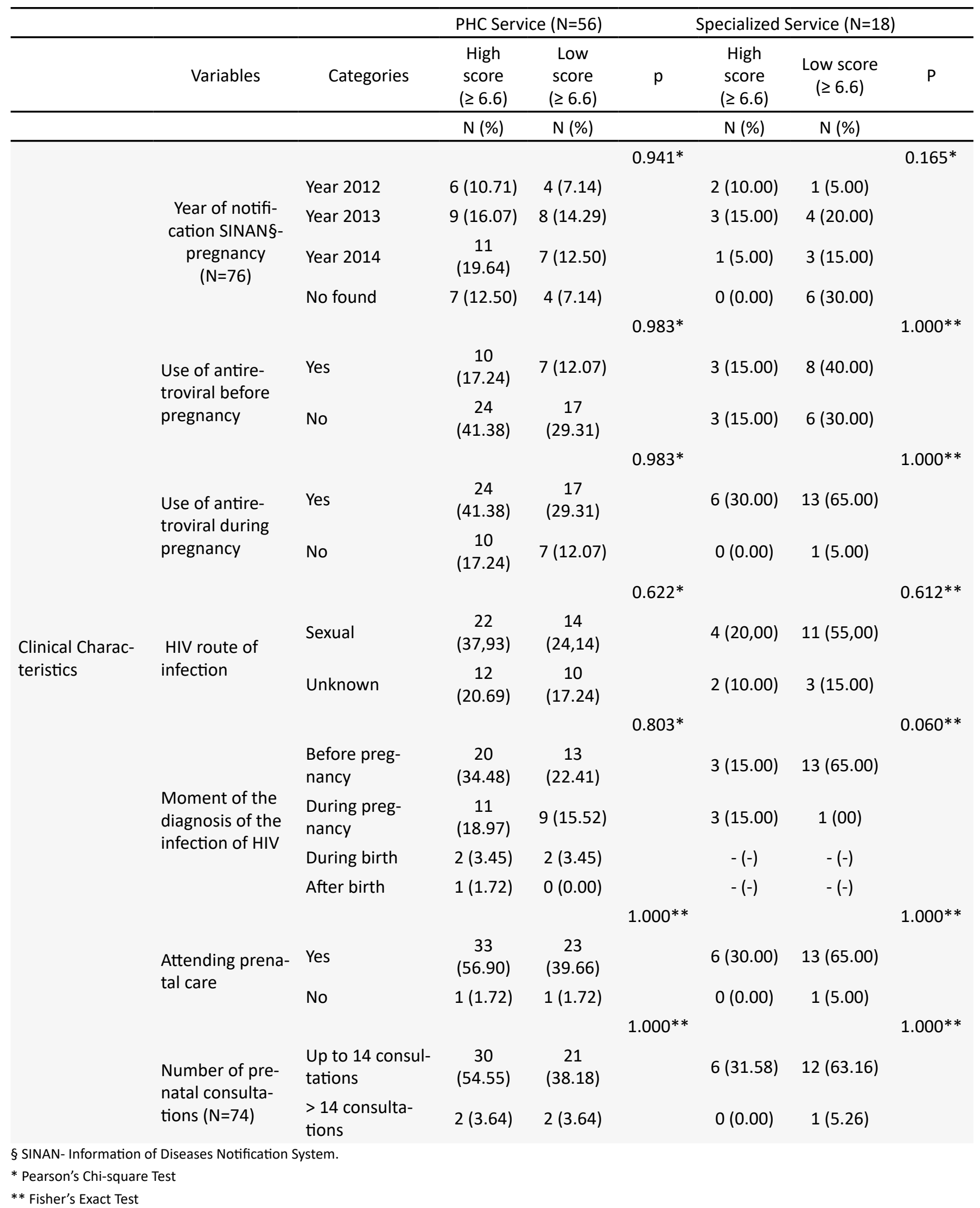


adopted as ideal. The low score evaluated by the participants in this research was convergent with general score also unsatisfactory ${ }^{6,25}$ in the users' experience of FHS of a city in the interior of other Brazilian state; ${ }^{26}$ as well as with the results of an evaluation study of health services, according to of resources (physical, human and material) and prenatal care process, developed in the BHU and FHS, which indicated deficient performance in both models, altough a little better in the FHS. ${ }^{27}$ This may indicate that the unsatisfactory evaluation is not exclusive of the serological condition, or of the type of service in which they are assisted, according to the results of other studies in the Brazilian context, the problem is in the attention to the woman, especially in the pregnancy-puerperal period. ${ }^{28,29}$

A national historical analysis of the quality of prenatal care identified good coverage, however, with high rates of inadequacies of the attention. ${ }^{30}$ It should be considered that the evaluation of the attention to people living with HIV recommends the adhesion to be a priority, in addition to counselling and testing, vertical transmission prevention, availability of human resources, equipment and of physical infrastructure. ${ }^{31}$

In relation to the association of high/low score with the sociodemographic and clinical characteristics, no variable was significantly associated, demonstrating that these characteristics did not interfere in the evaluation of these services, which suggests that the quality evaluation score, either of affiliation of the women to the PHV service, or to the specialized service, does not depend on their age, skin color, housing, marital status, instruction or occupation. The absence of significant association indicates, still, that the year of pregnancy, the moment of HIV diagnosis, the route of infection, the use of antiretroviral drugs before the pregnancy, the use of vertical transmission prophylaxis and the carrying out of the prenatal care did not interfere in the score either. Thus, it can be inferred that the score is not associated with the woman's characteristics, the pregnancy condition or the infection, but with the characteristics of the service itself, either from infrastructure resources or from actions.

One reiterates the importance of the active participation and the articulation between the $\mathrm{PHC}$ services and the specialized, in order that one can overcome the fragmentation of the actions of attention to health ${ }^{32}$, including reproductive and of management of infection, envisioning the woman who experiences these conditions, in search of the integrality of the care. ${ }^{33}$ One emphasizes the services integration for attention to the people living with $\mathrm{HIV}^{34}$, in which in the specificity of the women population must be since the attention to the sexual and reproductive health ${ }^{35}$, anti-HIV testing ${ }^{36,37}$ and continuity of attention in the puerperal period. ${ }^{38}$ These integrated actions among the services should compose the care lines to the women.

Therefore, in order to achieve the quality desired in the evaluation of the attention to health of women living with HIV, it is recommended to invest in the access of pregnant women to the points of the PHC, under the coordination of the PHC, with negotiation of attributions of each service, according to its technological density, in addition to the communication between them and qualification of professionals. Such investment may positively affect both the vertical transmission rates and the integrality in the attention to health and in the continuity of the pregnancy care, puerperium and childcare.

\section{CONCLUSION}

Despite the study's participants making use of the PHC as regular source of attention to health during the gestational period, the evaluation showed that both the PHC and the specialized service had unsatisfactory score. However, the PHC score approached the value considered ideal. This may have reflected on their choice as regular source of attention. Thus, it stands out the importance of its role in the coordination, monitoring and promotion of the attached population, including by sharing some actions to meet demands related to the HIV infection with the specialized service.

As to the limitations, the non-attendance of some participants to health services during the data collection period might have culminated in the loss of users who possibly search for the $\mathrm{PHC}$ services, influencing statistically the chance of the association for the comparison between the services. It should be noted that the instrument used is not specific to people living with HIV and the uniqueness of this instrument application to this population points to the need for the investment in researches that propose the construction and validation of specific instruments.

\section{FINIANCIAL SUPPORT}

This work was carried out with support from the Brazilian Federal Agency for Support and Evaluation of Graduate Education - Brazil (CAPES) - Financing Code 001. Master's degree fellowship awarded to Raquel Einloft Kleinubing.

\section{REFERENCES}

1. Ministério da Saúde (BR). Departamento de DST, Aids e Hepatites Virais. Direitos Humanos, Risco e Vulnerabilidade - DHRV. Plano Integrado de Enfrentamento da Feminização da Epidemia de Aids e Outas DSTs: Análise da Situação Atual e Proposta de Monitoramento. Brasília (DF): Ministério da Saúde; 2010.

2. Maliska ICA, Padilha MI, Andrade SR. Políticas voltadas às DSTS/ AIDS e sua integração político-assistencial no contexto do SUS: um estudo sobre o município de Florianópolis-SC. Texto Contexto (Florianópolis) Enferm [Internet]. 2014; [cited 2017 Aug 1]; 23(3):63947. Available from: http://www.scielo.br/pdf/tce/v23n3/pt_0104-0707tce-23-03-00639.pdf

3. Mendes EV. As redes de atenção à saúde. Brasília: Organização PanAmericana da Saúde; 2011.

4. Barbosa DVS, Barbosa NB, Najberg E. Regulação em Saúde: desafios à governança do SUS. Cad Saúde Coletiva [Internet]. 2016 Mar; [cited 2018 Aug 6]; 24(1):49-54. Available from: http://www.scielo.br/scielo. php?script=sci_arttext\&pid=S1414-462X2016000100049\&Ing=en

5. Lopes LM, Magnabosco GT, Andrade RLP, Ponce MAZ, Wysock $A D$, Ravanholi GM, et al. Coordenação da assistência prestada às pessoas que vivem com HIV/AIDS em um município do Estado de São Paulo, Brasil. Cad Saúde Pública [Internet]. 2014 Nov; [cited 2017 Aug 1]; 30(11):2283-97. Available from: http://www.scielo.br/pdf/csp/ v30n11/0102-311X-csp-30-11-2283.pdf

6. Palácio MB, Figueiredo MAC, Souza LB. O cuidado em HIV/AIDS 
e a Atenção Primária em Saúde: Possibilidades de Integração da Assistência. PSICO [Internet]. 2012 Jul/Sep; [cited 2017 Aug 1]; 43(3):360-7. Available from: http://revistaseletronicas.pucrs.br/ojs/index. php/revistapsico/article/view/9816/8237

7. Oliveira VBCA, Veríssimo MLOR. Assistência à saúde da criança segundo suas famílias: comparação entre modelos de Atenção Primária. Rev Esc Enferm USP [Internet]. 2015; [cited 2017 Aug 1]; 49(1):30-6. Available from: http://www.scielo.br/pdf/reeusp/v49n1/pt 0080-6234reeusp-49-01-0030.pdf

8. Oliveira MMC, Harzheim E, Riboldi J, Duncan BB. PCATool-ADULTO BRASIL: uma versão reduzida. Rev Bras Med Fam Comunidade [Internet]. 2013 Oct/Dec; [cited 2017 Aug 1]; 8(29):256-63. Available from: https://rbmfc.org.br/rbmfc/article/view/823/585

9. Stein AT. A avaliação dos serviços de saúde deve ser realizada com instrumentos validados. Epidemiol Serv Saúde [Internet]. 2013 Mar; [cited 2017 Aug 1]; 22(1):179-81. Available from: http://scielo.iec.gov. br/scielo.php?script=sci_arttext\&pid=S1679-49742013000100019

10. Mash R, Almeida M, Wong WCW, Kumar R, Pressentin KB. The roles and training of primary care doctors: China, India, Brazil and South Africa. Hum Resour Health [Internet]. 2015; [cited 2017 Aug 1]; 13:93. Available from: https://www.ncbi.nlm.nih.gov/pmc/articles/PMC4670546/

11. Marques AS, Freitas DA, Leão CDA, Oliveira SKM, Pereira MM, Caldeira AP. Atenção Primária e saúde materno-infantil: a percepção de cuidadores em uma comunidade rural quilombola. Ciênc Saúde Coletiva [Internet]. 2014; [cited 2017 Aug 1]; 19(2):365-71. Available from: http:// www.scielo.br/pdf/csc/v19n2/1413-8123-csc-19-02-00365.pdf

12. Pasarín MI, Berra S, González A, Benedicto AS, Tebé C, García-Altés $A$, et al. Evaluación de la atención primaria de salud: Primary Care Assessment Tools-Facility version para el sistema de salud español. Gac Sanit [Internet]. 2013 Feb; [cited 2018 Aug 6]; 27(1):12-8. Available from: http://scielo.isciii.es/scielo.php?script=sci_arttext\&pid $=$ S0213-91112013000100003

13. Lee JH, Choi YJ, Sung NJ, Kim SY, Chung SH, Kim J, et al. Development of the Korean primary care assessment tool-measuring user experience: tests of data quality and measurement performance. Int J Qual Health Care [Internet]. 2009 Apr; [cited 2018 Aug 6]; 21(2):103-11. Available from: https://academic.oup.com/intqhc/article/21/2/103/1822632

14. Yang H, Shi L, Lebrun LA, Zhou X, Liu J, Wang H. Development of the Chinese primary care assessment tool: data quality and measurement properties. Int J Qual Health Care [Internet]. 2013 Feb; [cited 2018 Aug 6]; 25(1):92-105. Available from: https://academic.oup.com/intqhc/ article/25/1/92/1938296

15. Jatrana S, Crampton P, Richardson K. Continuity of care with general practitioners in New Zealand: results from SoFIE-Primary Care. NZ Med J [Internet]. 2011 Feb; [cited 2018 Aug 6]; 124(1329):16-25. Available from: https://www.ncbi.nlm.nih.gov/pubmed/21475356

16. Berra S, Hauser L, Audisio Y, Mántaras J, Nicora V, Oliveira MMC, et al. Validez y fiabilidad de la versión argentina del PCAT-AE para evaluar la atención primaria de salud. Rev Panam Salud Publica [Internet]. 2013; [cited 2018 Aug 6]; 33(1):30-9. Available from: https://www.scielosp.org/ $\mathrm{pdf} / \mathrm{rpsp} / 2013 . \mathrm{v3} 3 \mathrm{n} 1 / 30-39 / \mathrm{es}$

17. Grupo PCAT.UY; Pizzanelli M, Ponzo J, Buglioli M, Toledo A, Casinelli M, Gómez A. Validación de Primary Care Assessment Tool (PCAT) en Uruguay. Rev Méd Urug [Internet]. 2011 Sep; [cited 2018 Aug 6]; 27(3):187-9. Available from: http://www.scielo.edu.uy/scielo. php?script=sci_arttext\&pid=S1688-03902011000300009

18. Cesar JA, Sutil AT, Santos GB, Cunha CF, Mendonza-Sassi RA. Assistência pré-natal nos serviços públicos e privados de saúde: estudo transversal de base populacional em Rio Grande, Rio Grande do Sul, Brasil. Cad Saúde Pública [Internet]. 2012 Nov; [cited 2017 Aug 1]; 28(11):2106-14. Available from: http://www.scielo.br/pdf/csp/v28n11/10. pdf

19. Andrade MS, Silva AF, Medeiros AK, Nascimento PW. Percepção dos usuários sobre adesão à terapia antirretroviral de alta atividade. Rev APS [Internet]. 2012 Jul/Sep; [cited 2017 Aug 1]; 15(3):299-305. Available from: https://aps.ufjf.emnuvens.com.br/aps/article/view/1416/659
20. Shimizu HE, Dutra EB, Trindade JS, Mesquita MS, Ramos MC. Índice de Responsividade da Estratégia Saúde da Família da Zona Urbana. Acta Paul Enferm [Internet]. 2016; [cited 2017 Aug 1]; 29(3):332-9. Available from: http://www.scielo.br/pdf/ape/v29n3/1982-0194-ape-29-03-0332.pdf

21. Ribeiro IM, Rosa AF, Felacio VCM. Avaliação dos serviços de assistência oferecidos aos portadores de HIV/AIDS. Rev Interd [Internet]. 2015 Oct/Nov; [cited 2018 Aug 6]; 8(4):71-81. Available from: https:// revistainterdisciplinar.uninovafapi.edu.br/index.php/revinter/article/ view/511

22. Loch AP, Nemes MIB, Santos MA, Alves AM, Melchior RB, Basso CR, et al. Avaliação dos serviços ambulatoriais de assistência a pessoas vivendo com HIV no Sistema Único de Saúde: estudo comparativo 2007/2010. Cad Saúde Pública [Internet]. 2018; [cited 2018 Aug 6] 34(2):e00047217. Available from: http://www.scielo.br/pdf/csp/v34n2/ en_1678-4464-csp-34-02-e00047217.pdf

23. Foresto JS, Melo ES, Costa CRB, Antonini M, Gir E, Reis RK Adesão à terapêutica antirretroviral de pessoas vivendo com HIV/ aids em um município do interior paulista. Rev. Gaúcha Enferm [Internet]. 2017 Apr; [cited 2018 Aug 3]; 38(1):e63158. Available from: http://www.scielo.br/scielo.php?script=sci_arttext\&pid=S198314472017000100406\&lng=en

24. Zambenedetti G, Silva RAN. Descentralização da atenção em HIV-Aids para a atenção básica: tensões e potencialidades. Physis [Internet] 2016; [cited 2018 Aug 6]; 26(3):785-806. Available from: http://www. scielo.br/pdf/physis/v26n3/0103-7331-physis-26-03-00785.pdf

25. Vitoria AM, Harzheim E, Takeda SP, Hauser L. Avaliação dos atributos da atenção primária à saúde em Chapecó, Brasil. Rev Bras Med Fam Comunidade [Internet]. 2013 Oct/Dec; [cited 2017 Aug 1]; 8(29):285-93. Available from: https://www.rbmfc.org.br/rbmfc/article/viewFile/832/589

26. Lima EFA, Sousa AI, Primo CC, Leite FMC, Lima RCD, Maciel ELN Avaliação dos atributos da atenção primária na perspectiva das usuárias que vivenciam o cuidado. Rev Latinoam Enferm [Internet]. 2015 May/ Jun; [cited 2018 Aug 6];23(3):553-9. Available from: http://www.scielo.br/ scielo.php?script=sci_arttext\&pid=S0104-11692015000300553\&lng=pt

27. Oliveira RLA, Fonseca CRB, Carvalhaes MABL, Parada CMGL. Avaliação da atenção pré-natal na perspectiva dos diferentes modelos na atenção primária. Rev Lat Am Enferm [Internet]. 2013; [cited 2018 Aug 6]; 21(2):[08 telas]. Available from: http://www.scielo.br/pdf/rlae/ v21n2/pt_0104-1169-rlae-21-02-0546.pdf

28. Leal MC, Theme-Filha MM, Moura EC, Cecatti JG, Santos LMP. Atenção ao pré-natal e parto em mulheres usuárias do sistema público de saúde residentes na Amazônia Legal e no Nordeste, Brasil 2010. Rev Bras Saúde Mater Infant [Internet]. 2015 Jan/Mar; [cited 2018 Aug 6]; 15(1):91-104. Available from: http://www.scielo.br/pdf/rbsmi/ v15n1/1519-3829-rbsmi-15-01-0091.pdf

29. Mafra RLP, Pereira ED, Varga IVD, Mafra WCB. Aspectos de gênero e vulnerabilidade ao HIV/aids entre usuários de dois dos Serviços de Atendimento Especializado em DST/aids de São Luís, Maranhão. Saúde Soc [Internet]. 2016; [cited 2018 Aug 6]; 25(3):64151. Available from: http://www.scielo.br/scielo. php?pid=S0104$12902016000300641 \&$ script=sci_abstract\&tIng $=\mathrm{pt}$

30. Araújo AJS, Santana IT, Sena AA, Barreto ES. Programas e políticas de saúde da mulher: avaliação da qualidade de atenção pré-natal. Rev Rede Cuid Saúde [Internet]. 2017; [cited 2018 Aug 6]; 11(1):1-14. Available from: http://publicacoes.unigranrio.edu.br/index.php/rcs/ article/view/4204/2374

31. Romão TC, Marson PG, Santos LF, Evangelista DR, Silva TBC. Critérios de avaliação da atenção para pessoas vivendo com HIV/ AIDS. Rev CEREUS [Internet]. 2017 May/Aug; [cited 2018 Aug 6]; 9(2):1-18. Available from: http://ojs.unirg.edu.br/index.php/1/article/ view/1552/536

32. Medeiros LB, Trigueiro DRSG, Silva DM, Nascimento JA, Monroe AA, Nogueira JA, et al. Integração entre serviços de saúde no cuidado às pessoas vivendo com aids: uma abordagem utilizando árvore de decisão. Ciênc Saúde Coletiva [Internet]. 2016; [cited 2018 Aug 6] 21(2):543-52. Available from: http://www.scielo.br/pdf/csc/v21n2/14138123-csc-21-02-0543.pdf 
33. Oliveira MAC, Pereira IC. Atributos essenciais da Atenção Primária e a Estratégia Saúde da Família. Rev Bras Enferm [Internet]. 2013; [cited 2017 Aug 1]; 66(no.spe):158-64. Available from: http://www.scielo.br/ pdf/reben/v66nspe/v66nspea20.pdf

34. Magnabosco GT, Lopes LM, Andrade RLP, Brunello MEF, Monroe AA, Villa TCS. Assistência ao HIV/aids: análise da integração de ações e serviços de saúde. Esc Anna Nery [Internet]. 2018 Jul; [cited 2018 Aug 6]; 22(4):e20180015. Available from: http://www.scielo.br/scielo. php?script=sci_arttext\&pid=S1414-81452018000400203\&lng=pt

35. Pinho AA, Cabral CS, Barbosa RM. Diferenças e similaridades entre mulheres que vivem e não vivem com HIV: aportes do estudo GENIH para a atenção à saúde sexual e reprodutiva. Cad Saúde Pública [Internet]. 2017; [cited 2018 Aug 6]; 33(12):e00057916. Available from: http://www.scielo.br/scielo.php?pid=S0102311X2017001205006\&script=sci_abstract\&tlng=pt
36. Guanabara MAO, Araújo MAL, Barros VL, Gondim APS, Pinheiro PMR, Oliveira FA. Gestantes com HIV/Aids acompanhadas em serviços públicos. Rev Enferm UFPI [Internet]. 2014 Apr/Jun; [cited 2017 Aug 1];3(2):25-32. Available from: http://www.ojs.ufpi.br/index.php/reufpi/ article/view/1838/pdf

37. Araújo EC, Monte PCB, Haber ANCA. Avaliação do pré-natal quanto à detecção de sífilis e HIV em gestantes atendidas em uma área rural do estado do Pará, Brasil. Rev Pan-Amaz Saude [Internet]. 2018 Mar [cited 2018 Aug 1]; 9(1):33-9. Available from: http://scielo.iec.gov.br/ scielo.php?script=sci_arttext\&pid=S2176-62232018000100033

38. Warley EM, Tavella S, Rosas A. Control de embarazo y postparto en mujeres infectadas por HIV. Medicina (B. Aires) [Internet]. 2017 Apr; [cited 2018 Aug 1]; 77(2):85-8. Available from: http://www.scielo.org. ar/scielo.php?script=sci_arttext\&pid=S0025-76802017000200002

\footnotetext{
${ }^{a}$ Article extracted from the Master Dissertation of authorship of Raquel Einloft Kleinubing, defended in 2015, Post-Graduate Program in Nursing. Federal University of Santa Maria, under the guidance of Cristiane Cardoso de Paula and co-orientation of Stela Maris de Mello Padoin. Full text available at: https:// repositorio.ufsm.br/bitstream/handle/1/7441/KLEINUBING,\%20RAQUEL\%20EINLOFT.pdf?isAllowed=y\&sequence=1
} 